\title{
An Exercise Program to Improve the Physical and Motor Efficiency after Double Trans-Femoral Lower Limb Amputation.
}

\section{Mohamed Kamal Moussa}

Lecturer, Faculty of Sport Education for Men, Alexandria University. Egypt.

\section{Wael Kamel El-Hawy}

Lecturer, Faculty of Sport Education for Men, Alexandria University. Egypt.

\section{Introduction and Research Problem}

$\mathrm{D}$ isability is a problem encountered by many countries in the world, especially in the developing countries. The Solutions to this problem are a must if development is to be maintained in such countries. This paper discusses physical disability which has many forms such as amputation arthritis, amyotrophy and paralysis.

A scientific study (by Kessler) states that during World War II about 18,000 American citizens lost parts of their bodies during military service. During the same period 120,000 American civilians lost some limbs in accidents. Thomas and Haddan estimated the number of annual amputations at 40,000. (17:74-81), (23:521-532)

The above mentioned data might be a good indicator of the number of amputations that might occur in a given community, especially in case statistics are not available. Such numbers might be the minimum of cases in developing countries if population is taken into consideration.

Amputation can be defined as removal of a limb or part of a limb as a result of interior or exterior causes, or congenital disabilities. (13:831-836), (21:3-12)

\section{Causes of Amputation}

- Tumours, malignant tumours, osteochondromatosis or cell tumours that necessitate amputation for fear of contagion, and when treatment is useless.

- Accidents and trauma

- Putridity of a limb wound, as in the case of gangrene, especially the germ, in which case amputation is of great importance.

- Congenital amputation, which is not considered by many studies as amputation because it is caused by atrophy in a given limb. (25:634-645), (11:875-883), (19:485)

Several rehabilitation specialists agree that post-operative left parts have their particular characteristics. The post-operative left parts of a limb plays an important role in rehabilitation after the healing of the amputation place. It also gives a clear indication of the new motor possibilities of this part which can be used after rehabilitation.

Amputation place is determined by means of protection, the muscles point of contact and the relationship with blood vessels and nerves (14:229-241), (18:465-469). The main 
characteristics that must be considered in the left part are:

- Length: length of the left part is a big advantage. This part should usually be shorter in the lower limb in consideration of the venous circulation of the blood and for safety reasons. This occurs in below knee amputation where many knee flexor and extensor muscles merge 10 centimetres below the joint (figure ....knee joint). As for the femur joint, the merging of the muscles along the thigh, especially the flexor and adductor of the femur joint causes the left part length to be something between 15 and 30 centimetres so as to keep some strength for the adductor muscles. It is also important for the other body joints to take into consideration safety of the left part and making the most use of the power of the flexor and the extensor and other muscles that move this part through the nearest joint.

- Shape of the left part: the end of this limb must be conical in shape because artificial limbs depend on lateral loading.

- Position of the wound: this must be liable to much movement or friction and it must also be in the form of a free-moving line.

- The tissue covering the left part: this part should be covered with skin and tissue under the skin and must not exist in the skin tissue so that movement can be easy without any flaccidity of the tissues (8:395-399), (16:901-904), (24:34-43)

\section{Rehabilitation for Amputation-Disabled Persons}

Post-amputation rehabilitation is a well organised process reflecting an integrated concept of intensive care for the patient from injury to return as a useful member of the society. This aim requires the cooperation of the surgeon, artificial limb specialist, the sport coach, the psychologist and everyone working in the field of rehabilitation. The patient starts rehabilitation after 2-3 weeks from the surgical operating date. During this time care is given to the healing of the position of the amputation, how it is adapted to the new position, preventing any muscle dysfunction, reviewing of the case, blood circulation problems, amputation ulcer, skin inflammations and similar problems. At the same time this process helps atrophy of the amputated part in preparation for fixing the artificial limb and legamenting the limbs, recently experimental research has been done to improve higher and lower artificial limbs reflecting the rapid progress in this field and requiring training and rehabilitation processes that must be compatible to all that is new (1:92), (7:139-144, 395-399), (9:559566), (20:227-235). Physical exercises, whether free or tool-based are very important in developing the physical and motor abilities for people in general and the disabled peoples in particular. Many physical exercises specialists agree that such exercises should be performed as a team activity. They are performed as free exercises (without tools) or using small tools or on bigger equipment in order to increase a person's physical and motor abilities. Exercises for special purposes are performed as a team activity as games in different sport and physical competitive activities or in recreational competitive championships or in 
sports events (5:40-44), (3:27-33), (4:24-32), (6:15-18), (2:29-31).

\section{Prosthetics}

The artificial leg (Prosthesis) consists of a costume fitted socket of the amputation place and belts to attach it to the body. The knee joint can be provided with belts to control motion and also the lower leg and the foot. In this way the prosthesis can be suitable to children and youth who have strong parts of the limbs that can endure the loading system when supporting the body and during movement. In case the processes includes belts and works in a manner similar to the normal walking movement, the position of the prosthesis above the knee joint does not prevent the movement of the joint (15:117129), (12:662-668), (22:157-171).

\section{Objectives of the research}

The research aims at improving some physical and motor abilities after double trans-femoral lower - limb amputation through:

- Improving the muscular strength of the muscular groups at upper limb, lower limb and trunk;

- Increasing the motion range of the trunk flexor and extensor muscles;

- Improving still and motor balance;

- Increasing the ability to climb up and down the staircase;

\section{Research hypotheses}

- The exercise program helps improve the muscular strength of the muscular groups at upper limb, lower limb and trunk;

- The exercise program helps improve the motion range of the trunk flexor and extensor muscles;

- The exercise program helps Improve still and motor balance

- The exercise program Increases the ability to climb up and down the staircase.

\section{Research procedures}

\section{Methodology}

The experimental method was used, being suitable for this type of research, pre- and post-measurements were taken of one experimental group.

\section{Research sample}

The study sample consisted of 3 elderly amputees with double amputation above the knee who had amputation performed within a month on the two limbs. Amputation was done in the same manner and by the same surgeon who recommended to start rehabilitation after making sure that the wound healed, no inflammation or tumours existed on the left part of the lower limb above the knee and the amputee's health was in a state of stability. The surgery was performed in Al Salama New Hospital, in Smouha, Alexandria. 
Homogeneity of sample subjects in the basic variables:

Table 1

Statistic Description of Elementary Data of Research Sample

\begin{tabular}{|c|c|c|c|c|}
\hline Variables & Mean & Median & Standard Deviation & Contortion Co-efficient \\
\hline Height in cm & 169.667 & 170 & 1.366 & $\mathbf{- 0 . 5 2 3}$ \\
\hline Weight in kgm & 90.667 & 91 & 4.926 & $\mathbf{- 0 . 1 5 2}$ \\
\hline Age in years & 56.667 & 57 & 1.466 & $\mathbf{- 0 . 6 2 3}$ \\
\hline
\end{tabular}

Table 1 shows that the contortion co-efficient Height was measured to the nearest $0.5 \mathrm{~cm}$ value of the variables was 3 , indicating that using a stadiometer.

research sample was below the normal curve.

Homogeneity of sample subjects in physical and motor measurements:

Table 2

Statistic Description of Data before Experiment

\begin{tabular}{|c|c|c|c|c|c|}
\hline & Variables & Mean & Standard & $\begin{array}{l}\text { Kolmogorov- } \\
\text { Smirnov } 7\end{array}$ & Sig. \\
\hline & $\begin{array}{c}\text { strength of trunk flexor } \\
\text { muscles }\end{array}$ & 10.333 & 0.577 & 0.667 & 0.766 \\
\hline & $\begin{array}{c}\text { strength of trunk extensor } \\
\text { muscles }\end{array}$ & 9.500 & 0.866 & 0.667 & 0.766 \\
\hline & $\begin{array}{c}\text { strength of femoral flexor } \\
\text { muscles }\end{array}$ & 1.500 & 0.500 & 0.303 & 1.000 \\
\hline & $\begin{array}{c}\text { strength of femoral extensor } \\
\text { muscles }\end{array}$ & 1.417 & 0.520 & 0.506 & 0.960 \\
\hline & $\begin{array}{c}\text { strength of femoral adductor } \\
\text { muscles }\end{array}$ & 1.833 & 0.289 & 0.667 & 0.766 \\
\hline Muscular & $\begin{array}{c}\text { strength of femoral abductor } \\
\text { muscles }\end{array}$ & 1.833 & 0.289 & 0.667 & 0.766 \\
\hline Strength (kg) & $\begin{array}{c}\begin{array}{c}\text { strength of shoulder joint } \\
\text { flexor muscles }\end{array} \\
\end{array}$ & 18.333 & 0.577 & 0.667 & 0.766 \\
\hline & $\begin{array}{c}\text { strength of shoulder joint } \\
\text { extensor muscles }\end{array}$ & 14.000 & 1.000 & 0.303 & 1.000 \\
\hline & $\begin{array}{c}\text { strength of shoulder joint } \\
\text { adductor muscles }\end{array}$ & 11.667 & 0.577 & 0.667 & 0.766 \\
\hline & $\begin{array}{l}\text { strength of shoulder joint } \\
\text { abductor muscles }\end{array}$ & 11.667 & 0.577 & 0.667 & 0.766 \\
\hline & $\begin{array}{c}\text { strength of elbow joint flexor } \\
\text { muscles }\end{array}$ & 14.333 & 0.577 & 0.667 & 0.766 \\
\hline & $\begin{array}{l}\text { strength of elbow joint } \\
\text { extensor muscles }\end{array}$ & 13.333 & 0.577 & 0.667 & 0.766 \\
\hline
\end{tabular}

Table 2 shows that the Kolmogorov-Smirnov near to normalcy and belong to a $\mathrm{Z}$ value ranged between 0.303 and 0.667 , homogeneous community. which is insignificant at the level of 0.05 , indicating that the measurements reached are

Muscular strength was measured by dynamometer. 
Table 3

Statistic Description of Motion Range Data before Experiment $(\mathbf{N}=3)$

\begin{tabular}{|c|c|c|c|c|c|}
\hline \multicolumn{2}{|c|}{ Variables } & Mean & $\begin{array}{c}\text { Standard } \\
\text { Deviation }\end{array}$ & $\begin{array}{c}\text { Kolmogorov } \\
\text {-Smirnov Z }\end{array}$ & Sig. \\
\hline $\begin{array}{c}\text { Motio } \\
\mathbf{n}\end{array}$ & $\begin{array}{c}\text { measurement of the motion range } \\
\text { of trunk extensor muscles (the } \\
\text { distance between sternum and the } \\
\text { ground ( cm) }\end{array}$ & 5.333 & 0.577 & 0.667 & 0.766 \\
\cline { 2 - 5 }$(\mathrm{cm})$ & $\begin{array}{c}\text { measurement of the motion range } \\
\text { of trunk flexor muscles (the } \\
\text { distance bending the trunk forward } \\
\text { from long sitting ( cm) }\end{array}$ & -12.000 & 1.000 & 0.303 & 1.000 \\
\hline
\end{tabular}

Table 3 shows that the Kolmogorov-Smirnov near to normalcy and belong to a $\mathrm{Z}$ value ranged between 0.303 and 0.667 , homogeneous community.

which is insignificant at the level of 0.05, Motion range for trunk was measured by indicating that the measurements reached are measuring scale.

Table 4

Statistic Description of Balance Data before Experiment $(\mathrm{N}=3)$

\begin{tabular}{|c|c|c|c|c|c|}
\hline \multicolumn{2}{|c|}{ Variables } & Mean & $\begin{array}{c}\text { Standard } \\
\text { Deviation }\end{array}$ & $\begin{array}{c}\text { Kolmogorov- } \\
\text { Smirnov Z }\end{array}$ & Sig. \\
\hline & Still balance with the walker & 7.333 & 2.082 & 0.506 & 0.960 \\
\cline { 2 - 6 } & Motor balance during 3 m/s & 52.667 & 3.055 & 0.438 & 0.991 \\
\cline { 2 - 6 } $\begin{array}{c}\text { Balance } \\
\text { (per } \\
\text { second) }\end{array}$ & $\begin{array}{c}\text { Climbing up and down the } \\
\text { staircase (number) }\end{array}$ & $\mathbf{0 . 3 3 3}$ & $\mathbf{0 . 5 7 7}$ & 0.667 & 0.766 \\
\cline { 2 - 6 } & Walking distance ( m) & 4.000 & 1.000 & 0.303 & 1.000 \\
\hline
\end{tabular}

Table 4 shows that the Kolmogorov-Smirnov $\mathrm{Z}$ value ranged between 0.303 and 0.667 , which is insignificant at the level of 0.05 , indicating that the measurements reached are near to normalcy and belong to a homogeneous community.

Balance was measured by stopwatch.

\section{Research measurements and tests}

- Age to the nearest year

- Height and weight measured by a restameter

- Measurements of the muscular strength of the lower limb (by dynamometer)
- strength of trunk extensor muscles

- strength of trunk flexor muscles

- strength of femoral extensor muscles

- $\quad$ strength of femoral flexor muscles

- strength of femoral adductor muscles

- strength of femoral abductor muscles

- Thigh circumference measurements (by meter tape)

- measurement of the motion range of the trunk (by measuring scale) 
- measurement of the motion range of trunk extensor muscles (by measuring scale)

- measurement of the motion range of trunk flexor muscles

- Still balance and motor balance

- Measurement of the muscular strength (by dynamometer)

- strength of shoulder joint flexor muscles

- strength of shoulder joint extensor muscles

- strength of shoulder joint adductor muscles

- strength of shoulder joint abductor muscles

- strength of elbow joint flexor muscles

- strength of elbow joint extensor muscles

- measuring the motor efficiency

- climbing up and down the staircase (by number of stair scales)

- walking (by centimetre)

\section{Executive procedures of the research}

\section{The pilot study}

A pilot study was conducted in the period $15 / 1 / 2012$ - 18/1/2012 on a sample of 2 patients exclusive of the basic sample of 3 patients. The aims of the pilot study were as follows:

- Identifying whether the content of the program is compatible with the study sample;

- Identifying the methods and means most appropriate to double transfemoral amputees, especially wheelchairs, prosthetics, walkers and crutches;

- Identifying the organizational approach to deal with the case to make sure of the availability of security and safety factors;

- Making sure of the security and safety of instruments and means used on the sample subjects;

- Identifying difficulties encountered by researchers during the application of the program

Results of the research showed that the program content is appropriate to the patients studied. A number of points must however be taken into consideration:

- There must be interval rest periods when performing the free exercises and tool exercises;

- Alternating movement should be allowed when necessary;

- Giving due attention to the patient's psychological state during application of the program, noting any change in the expressions on his/her face and trying to understand his/her needs;

- Perfecting the performance by the patient is not necessary. $\mathrm{He} / \mathrm{she}$ should only perform according to his/her abilities and potentials;

- Exercises with weights must be gradual;

- Weights must be standardized.

\section{Pre-measurements}

Pre - measurements and pre-tests were done on some physical and motor abilities of the research sample in the period 20/01/2012 27/01/2012. 


\section{Applying the exercise program}

The free and tool exercise program was applied in the period 29/01/2012 27/05/2012. it took 12 weeks to apply at the rate of 3 units per week (Sundays, Tuesdays and Thursdays). The time for the whole unit: $60 \mathrm{~m}-75 \mathrm{~m}$ distributed as follows: preparation and warm-up: $07 \mathrm{~m}$. 30s; the basic component of the program: $40 \mathrm{~m}-60 \mathrm{~m}$, using free and tool physical exercises; closing: $07 \mathrm{~m}$. 30s. the following points were taken into consideration:

- Gradual shifting from easy to difficult loads and from simple to complex loads;

- The use of low-intensity interval training;

- Principle of load and rest

\section{Post-measurements}

Post-Physical and motor measurements and tests were conducted on the research group in the period 28/05/2012-05/06/2012

\section{Statistical treatments}

Mean

Standard deviation

$\mathrm{T}$ calculated value

Kolmogorov- Smirnof Z

Improvement percentage

\section{Result presentation and discussion}

Significant differences between pre- and post- measurements

of the research group

Table 5

Significance of Differences between Pre-Measurements and Post-Measurements in the Muscular Strength Tests $(\mathbf{N}=3)$

\begin{tabular}{|c|c|c|c|c|c|c|c|c|c|c|}
\hline & \multirow{2}{*}{ Variables } & \multicolumn{2}{|c|}{ Pre-measurements } & \multicolumn{2}{|c|}{ Post-measurements } & \multirow{2}{*}{ 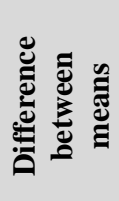 } & \multirow{2}{*}{ 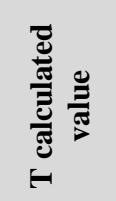 } & \multicolumn{2}{|c|}{$\begin{array}{l}\mathrm{Z} \text { value and } \\
\text { significance }\end{array}$} & \multirow{2}{*}{ 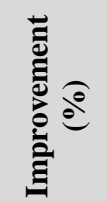 } \\
\hline & & mean & $\begin{array}{l}\text { standard } \\
\text { deviation }\end{array}$ & mean & $\begin{array}{l}\text { Standard } \\
\text { deviation }\end{array}$ & & & $\mathbf{Z}$ & Sig & \\
\hline \multirow{8}{*}{ 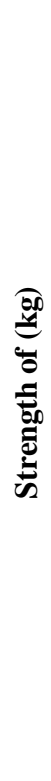 } & $\begin{array}{l}\text { Trunk flexor } \\
\text { muscle }\end{array}$ & 10.333 & 0.577 & 18.333 & 0.577 & 8.000 & $16.971 *$ & 2.023 & 0.043 & 77.419 \\
\hline & $\begin{array}{c}\text { Trunk extensor } \\
\text { muscle }\end{array}$ & 9.500 & 0.866 & 15.667 & 0.577 & 6.167 & $10.262 *$ & 2.023 & 0.043 & 64.912 \\
\hline & $\begin{array}{c}\text { Femoral flexor } \\
\text { muscle }\end{array}$ & 1.500 & 0.500 & 7.667 & 1.528 & 6.167 & $6.645 *$ & 1.964 & 0.050 & 411.111 \\
\hline & $\begin{array}{c}\text { Femoral } \\
\text { extensor muscle }\end{array}$ & 1.417 & 0.520 & 5.000 & 0.000 & 3.583 & $11.926 *$ & 2.087 & 0.037 & 252.941 \\
\hline & $\begin{array}{c}\text { Femoral } \\
\text { adductor muscle }\end{array}$ & 1.833 & 0.289 & 4.333 & 0.577 & 2.500 & $6.708 *$ & 2.023 & 0.043 & 136.364 \\
\hline & $\begin{array}{c}\text { Femoral } \\
\text { abductor muscle }\end{array}$ & 1.833 & 0.289 & 3.833 & 0.289 & 2.000 & $8.485 *$ & 2.023 & 0.043 & 109.091 \\
\hline & $\begin{array}{l}\text { Shoulder joint } \\
\text { flexor muscle }\end{array}$ & 18.333 & 0.577 & 33.667 & 1.528 & 15.333 & $16.263 *$ & 1.993 & 0.046 & 83.636 \\
\hline & $\begin{array}{l}\text { Shoulder joint } \\
\text { extensor muscle }\end{array}$ & 14.000 & 1.000 & 31.667 & 1.155 & 17.667 & $20.032 *$ & 1.993 & 0.046 & 126.190 \\
\hline
\end{tabular}




\begin{tabular}{|c|c|c|c|c|c|c|c|c|c|}
\hline \multirow{2}{*}{ Variables } & \multicolumn{2}{|c|}{ Pre-measurements } & \multicolumn{2}{|c|}{ Post-measurements } & \multirow{2}{*}{ 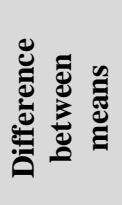 } & \multirow{2}{*}{ 冚 } & \multicolumn{2}{|c|}{$\begin{array}{l}Z \text { value and } \\
\text { significance }\end{array}$} & \multirow{2}{*}{ 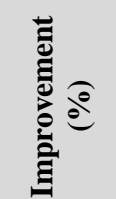 } \\
\hline & mean & $\begin{array}{l}\text { standard } \\
\text { deviation }\end{array}$ & mean & $\begin{array}{l}\text { Standard } \\
\text { deviation }\end{array}$ & & & $\mathbf{Z}$ & Sig & \\
\hline $\begin{array}{c}\text { Shoulder joint } \\
\text { adductor muscle }\end{array}$ & 11.667 & 0.577 & 25.667 & 0.577 & 14.000 & 29.698* & 2.023 & 0.043 & 120.000 \\
\hline $\begin{array}{c}\text { Shoulder joint } \\
\text { abductor muscle }\end{array}$ & 11.667 & 0.577 & 25.333 & 0.577 & 13.667 & 28.991* & 2.023 & 0.043 & 117.143 \\
\hline $\begin{array}{l}\text { Elbow joint } \\
\text { flexor muscle }\end{array}$ & 14.333 & 0.577 & 33.333 & 0.577 & 19.000 & $40.305^{*}$ & 2.023 & 0.043 & 132.558 \\
\hline $\begin{array}{c}\text { Elbow joint } \\
\text { extensor muscle }\end{array}$ & 13.333 & 0.577 & 33.000 & 1.000 & 19.667 & $29.500 *$ & 1.993 & 0.046 & 147.500 \\
\hline
\end{tabular}

T value significant at the level of $0.05=4.3$

Table 5 and figure 1 about significance of differences between pre-measurements and post-measurements in the muscular strength tests show differences between the two types of measurements in the muscular strength tests at the level of 0.05 , with the $\mathrm{T}$ value ranging between 6.645 and 40.305. This value is higher than tabular $\mathrm{T}$ value at the level of 0.05 . In consideration of the small size of the sample, the $\mathrm{Z}$ test was also conducted to identify differences in small samples. Results showed that there are significant differences between the premeasurements and post-measurements in strength variables, favoring postmeasurements with $\mathrm{Z}$ ranging between 1.964 and 2.087. These values are significant at the level of 0.05 . Percentile differences ranged between $64.912 \%$ and $411.111 \%$ in muscular strength. This improvement in muscular strength of muscle groups in the upper and lower limbs is attributed to the nature of the tool exercise program (medical balls, different and standardized weights, rubber bands, divided boxes, etc) and the free exercise program. The program improved the strength factor in muscle groups working on the two arms including the flexor, extensor, adductor and abductor muscles which had a great effect on increasing the motor ability of the research sample subjects and their ability to easily carry the weight of the left part after amputation, supported by the walker and the crutches. The program also improved the muscular strength of muscles working on the trunk, which had a positive effect on the ability to control the prosthesis, and which plays a great role in the muscular work of the femur joint that has lost much of the muscle working on it as a result of the amputation below the femur and the muscle groups of the lower limb. Application by the sample subjects of the tests measuring muscular strength, and strength exercises included in the program had a positive effect on research sample. Psychologically speaking, sample subjects had some compensation in exerting the maximum effort, when performing theses exercises, for the disability of the lower limb. The above able also shows an obvious improvement in the muscular strength of the flexor, extensor, adductor and abductor femoral joint muscles. This had a positive effect on carrying the weight of the prosthesis, representing $2-4 \mathrm{kgm}$ through the gradual shifting when performing the free and tool exercises, using the artificial limb. 
Figure 1

The mean of the pre-measurement and post-measurement of the experimental research group in muscular strength

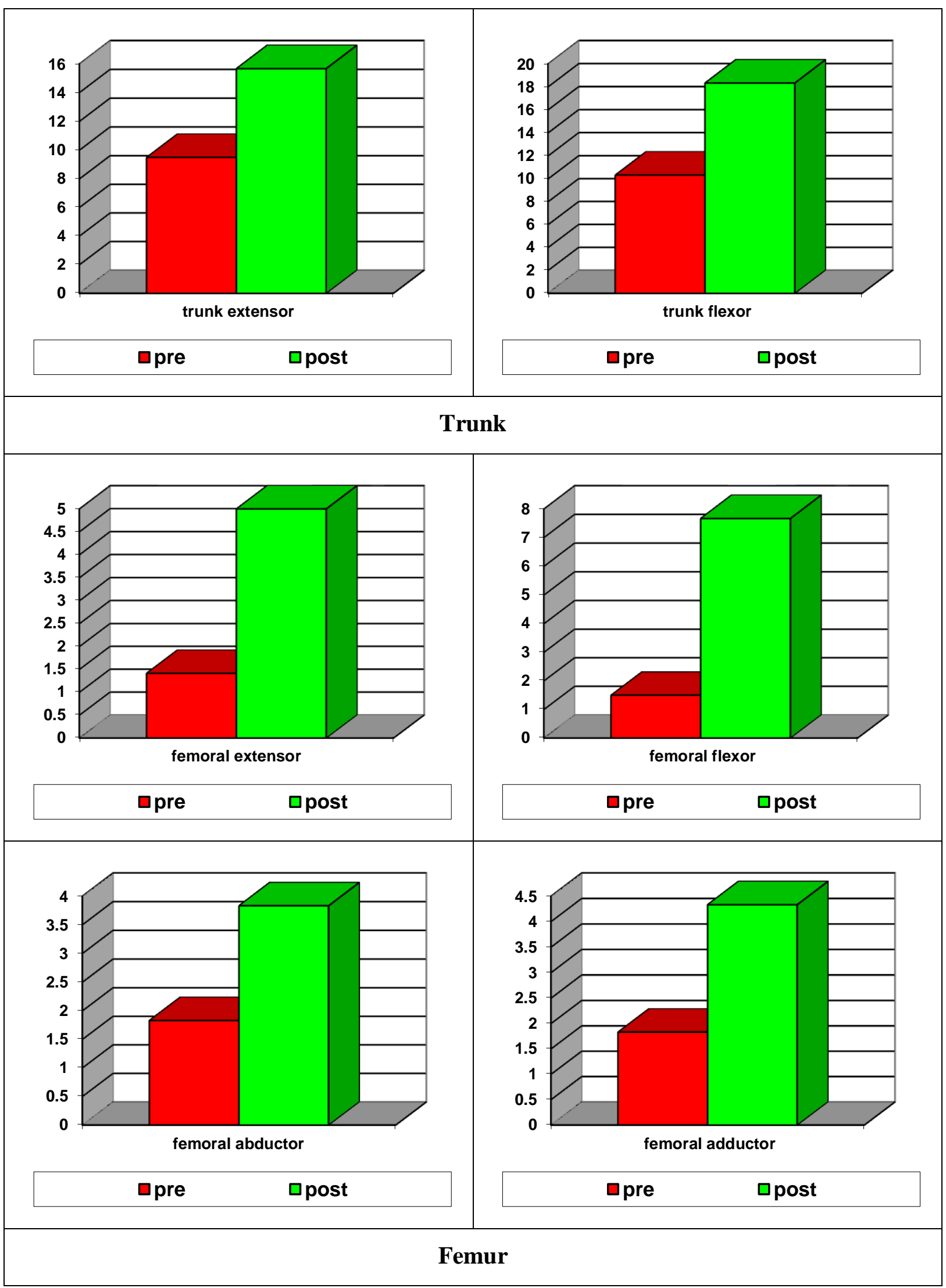


Figure 2

The mean of the pre-measurement and post-measurement of the experimental research group in muscular strength

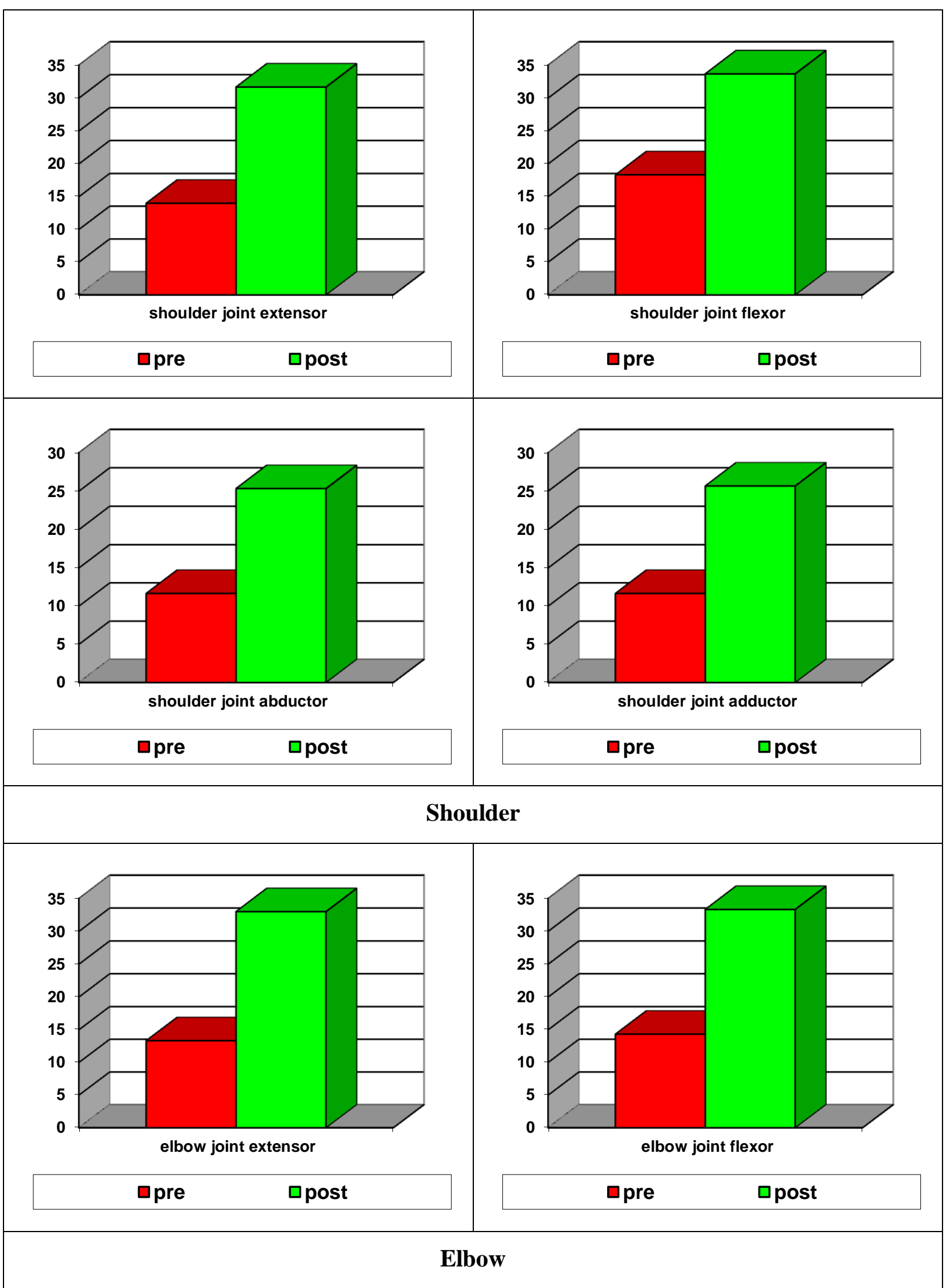


Table 6

Significance of Differences between Pre-Measurements and Post-Measurements in the Motion Range Tests $(\mathbf{N}=3)$

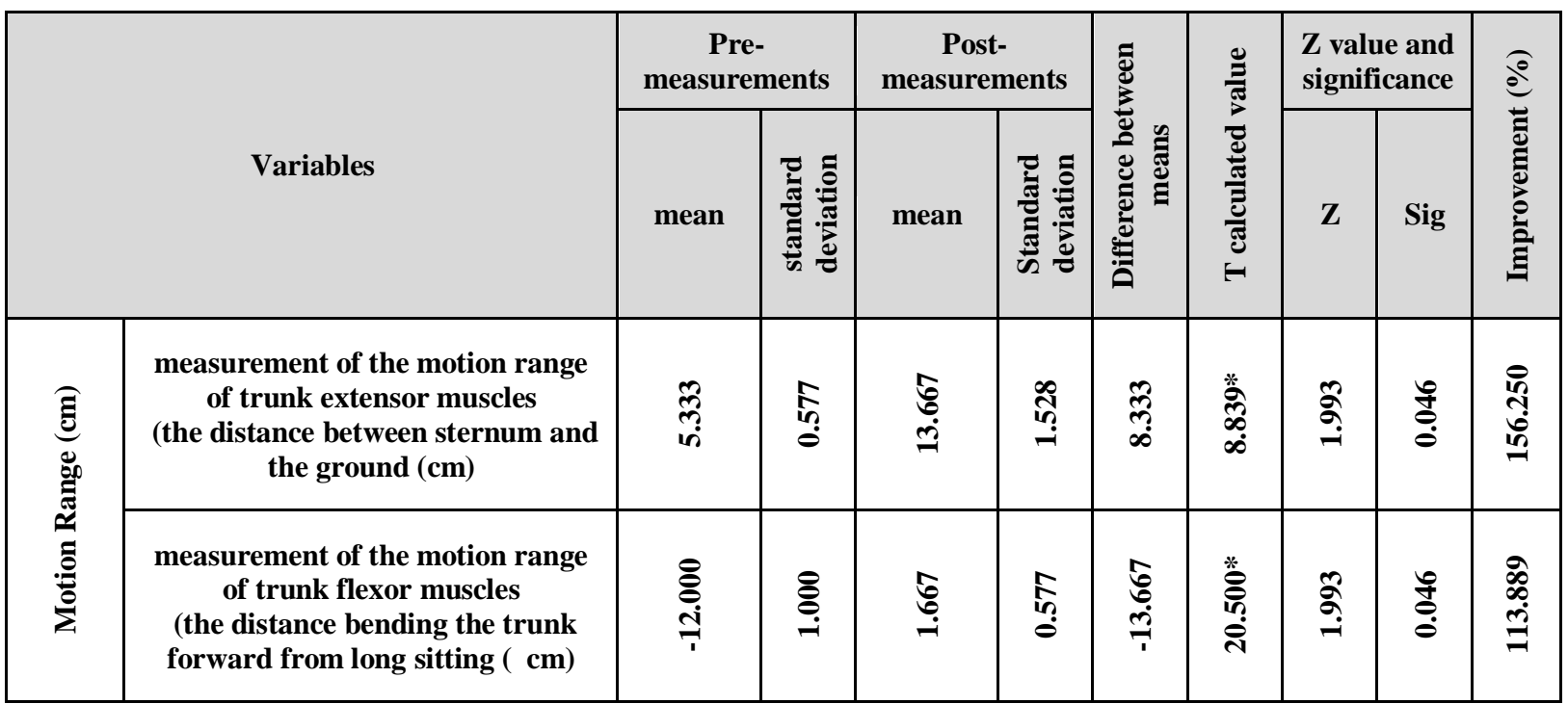

T value significant at the level of $0.05=4.30$

Table 6 and figure 2 about significance of differences between pre-measurements and post-measurements in the motion range tests show differences between the two types of measurements in the motion range tests at the level of 0.05 , with the $\mathrm{T}$ value ranging between 8.839 and 20.500. This value is higher than tabular $\mathrm{T}$ value at the level of 0.05 . In consideration of the small size of the sample, the $\mathrm{Z}$ test was also conducted to identify differences in small samples. Results showed that there are significant differences between the pre-measurements and postmeasurements in strength variables, favoring post-measurements with $\mathrm{Z}$ ranging between 1.993. This value is significant at the level of 0.05 . Percentile differences ranged between $156.250 \%$ and $113.889 \%$ in motion range. The improvement in the measurements of the motion range of the flexor and extensor trunk muscles is attributed to the nature of the program applied to the research sample, and the various and numerous exercises and their content. When performing an exercise, motion is made around one particular axis, i.e. joint. This is why muscles working on the joint, ligaments and tendons are affected by the exercise whether the aim of the exercise is developing strength, flexibility, motion range or coordination. The program applied included several over-extension exercises which make the muscle groups working on the joint, ligaments and tendons subject to a stronger external effect. This had a positive effect on the motor performance of the research sample subjects in their daily life and helped them be self-dependent. Various motion range exercises were used with the research sample subjects because the range motion and flexibility are very important for the amputees since they reduce the risks of back pain, a problem likely to be encountered by amputees. 
Figure 3

The mean of the pre-measurement and post-measurement of the experimental research group in motion range

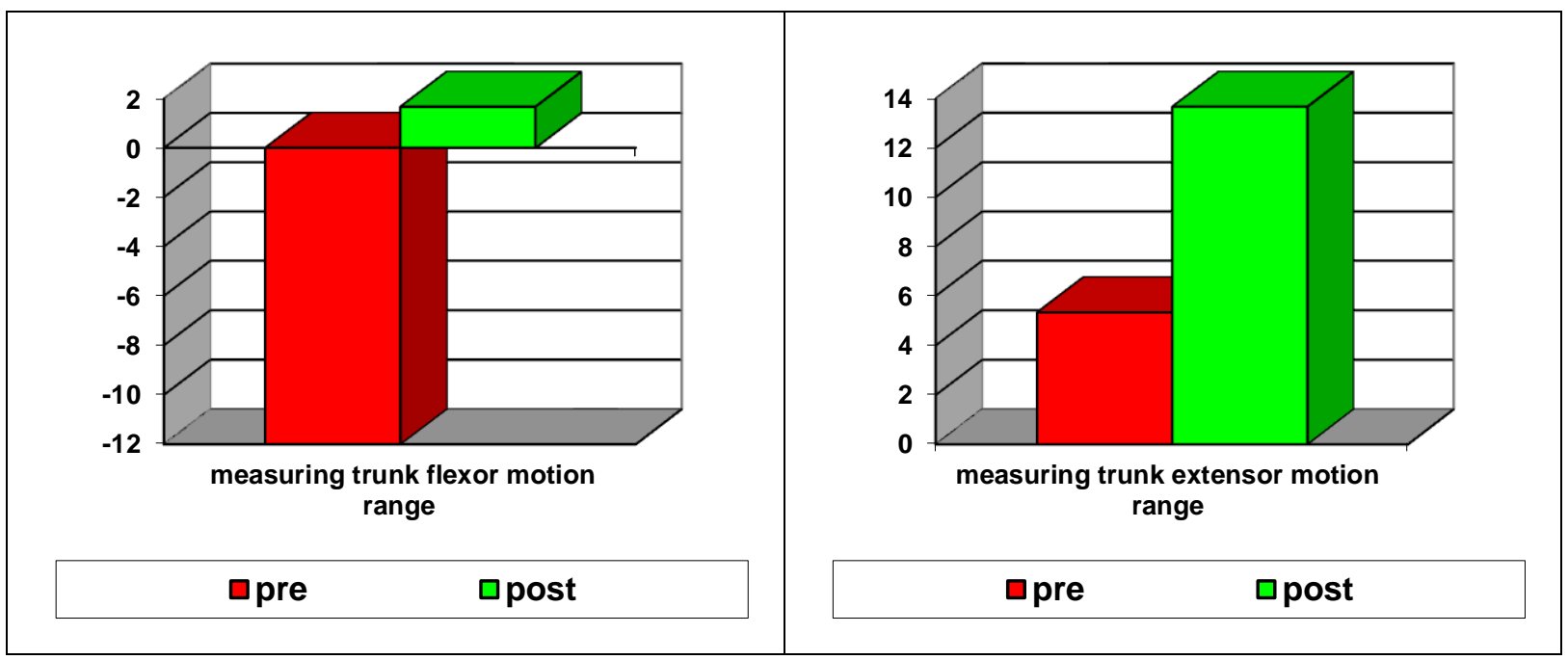

Table 7

Significance of Differences between Pre-Measurements and Post-Measurements in the Balance Tests $(\mathrm{N}=3)$

\begin{tabular}{|c|c|c|c|c|c|c|c|c|c|c|}
\hline & \multirow{2}{*}{ Variables } & \multicolumn{2}{|c|}{ Pre-measurements } & \multicolumn{2}{|c|}{$\begin{array}{c}\text { Post- } \\
\text { measurements }\end{array}$} & \multirow{2}{*}{ 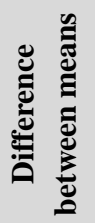 } & \multirow{2}{*}{ 冚 } & \multicolumn{2}{|c|}{$\begin{array}{l}Z \text { value and } \\
\text { significance }\end{array}$} & \multirow{2}{*}{ 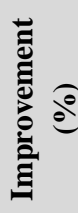 } \\
\hline & & mean & $\begin{array}{l}\text { standard } \\
\text { deviation }\end{array}$ & mean & $\begin{array}{l}\text { Standard } \\
\text { deviation }\end{array}$ & & & $\mathbf{Z}$ & Sig & \\
\hline \multirow{4}{*}{ 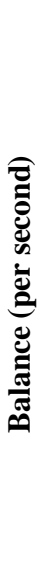 } & Stil balance with walker & $\stackrel{m}{r}$ & 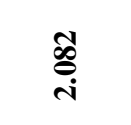 & 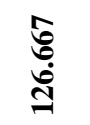 & $\stackrel{ }{\bar{b}}$ & 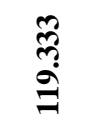 & 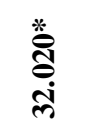 & ه̆ & 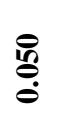 & $\stackrel{?}{\stackrel{\widehat{V}}{\sigma}}$ \\
\hline & $\begin{array}{c}\text { Motor balance of } 3 \mathrm{~m} / \mathrm{s} \\
\text { walking }\end{array}$ & $\begin{array}{l}5 \\
\text { ì } \\
\text { in }\end{array}$ & $\stackrel{\mathscr{c}}{\mathscr{c}}$ & $\begin{array}{l}\hat{8} \\
\dot{ \pm}\end{array}$ & $\stackrel{n}{n}$ & 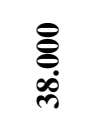 & 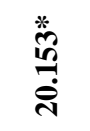 & گ̆ & $\stackrel{\text { 巳o }}{\stackrel{0}{0}}$ & $\frac{i}{i}$ \\
\hline & $\begin{array}{c}\text { Climb up and down the } \\
\text { staircase (no) }\end{array}$ & $\ddot{\tilde{m}}$ & $\stackrel{5}{n}$ & 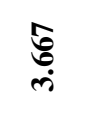 & $\stackrel{n}{n}$ & ले & $\stackrel{*}{\circ}$ & 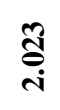 & $\stackrel{?}{巳}$ & 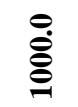 \\
\hline & Walking distance (m) & 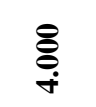 & 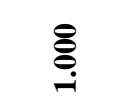 & $\begin{array}{l}\hat{b} \\
\stackrel{0}{0} \\
a\end{array}$ & $\stackrel{N}{i n g}$ & $\begin{array}{l}\hat{b} \\
\text { in } \\
0\end{array}$ & 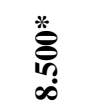 & گ̆ & 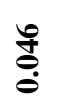 & 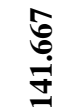 \\
\hline
\end{tabular}

*T value significant at the level of $0.05=4.30$

Table 7 and figure 3 about significance of differences between pre-measurements and post-measurements in the balance tests show differences between the two types of measurements in balance tests at the level of 0.05 , with the $\mathrm{T}$ value ranging between 7.071 and 32.020. This value is higher than tabular $\mathrm{T}$ value at the level of 0.05 . In consideration of the small size of the sample, the $\mathrm{Z}$ test was also conducted to identify differences in small samples. Results showed that there are significant differences between the premeasurements and post-measurements in balance variables, favoring postmeasurements with $\mathrm{Z}$ ranging between 1.964 and 2.023. These values are significant at the level of 0.05 . Percentile differences ranged between $72.152 \%$ and $1627.3 \%$. The improvement in still and motor balance is attributed to the nature of the program 
applied to the research sample and its content of balance exercises, whether these are free or performed with standardized tools, gradually shifting from easy to difficult exercises. The program had an obvious effect in helping the research sample subjects stand still or walk a short distance. The program exercises that improve strength and motion range also improved balance, being a complex physical element. Physical exercises, whether free or with tools, develop physical traits of people in general and he disabled in particular because they use certain parts of the body in the appropriate position. Results of this study showed that the muscular strength of the muscle group working on the upper limb and the left part of the lower limb has improved as a result of using the free and tool exercise program. The motion range of the flexor and extensor trunk muscles has also improved, and so has the still and motor balance element, which had an effect in improving walking forwards and backwards as shown in the above table. Improvement also occurred in climbing up and down the staircase using the prosthesis. Research sample subjects could also live as normal people satisfying their daily needs.

Figure 4

The mean of the pre-measurement and post-measurement of the experimental research group in motion range

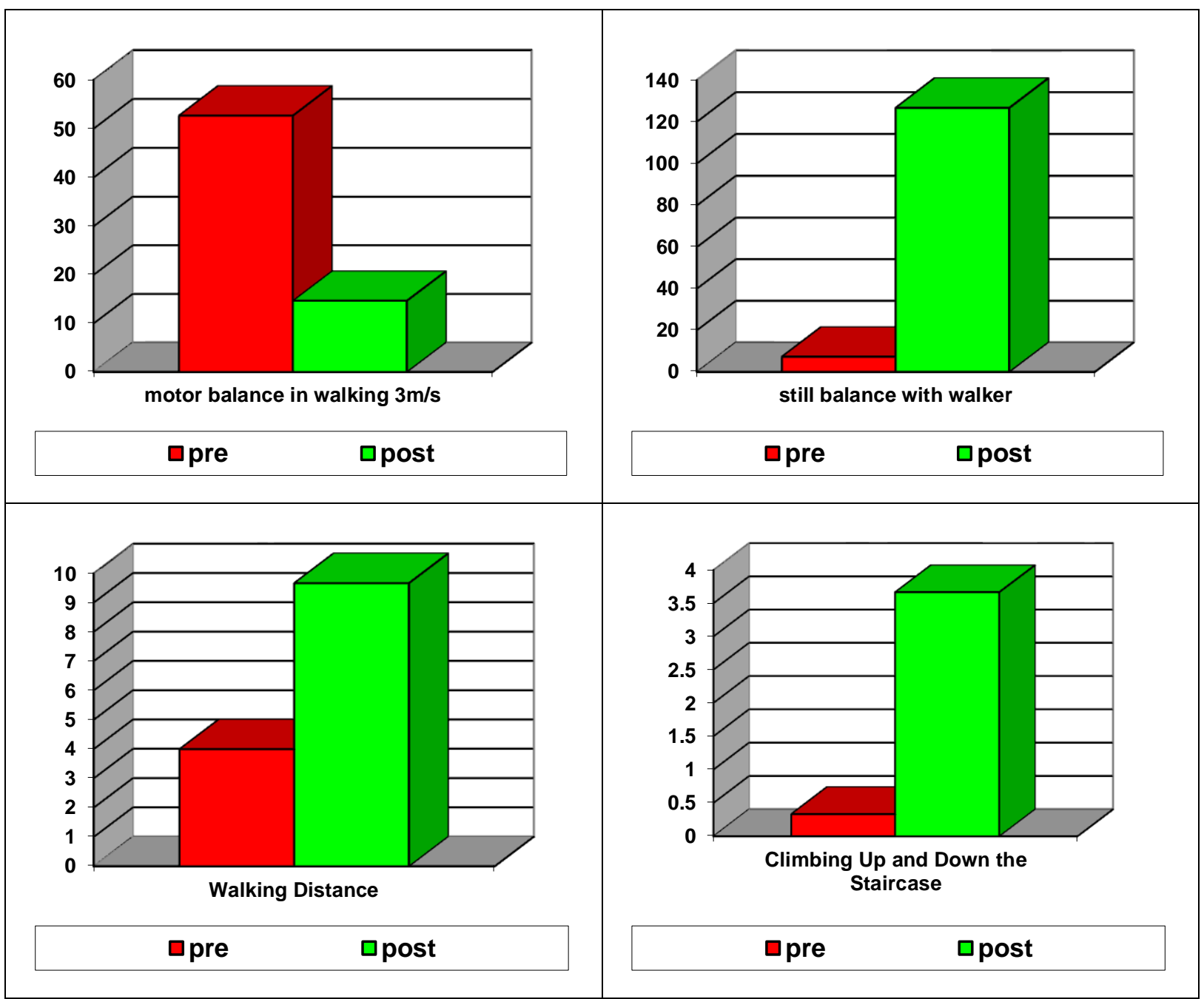




\section{Conclusions}

In the light of the research aims, results of the statistical analysis and results of the application of the exercise program, the following conclusions were reached:

- There are statistically significant differences between premeasurements and postmeasurements, favouring postmeasurements of the physical and motor abilities studied.

- There was an improvement in the muscular strength of the muscle groups working on the upper limb, lower limb and the trunk.

- There was an increase in the motion range of the flexor and extensor trunk muscles.

- There was an improvement in still and motor balance.

- There was an increase in the ability to climb up and down the staircase.

\section{Recommendations}

It is recommended to:

- Apply the program used in this current study, in view of the positive effect it has had as shown in the research results;

- Follow up, in a scientific manner, taking periodic measurements, of the physical and motor efficiency of the amputees after double trans-femoral amputation;

- Conducting further studies on the subject for different age groups.

\section{References}

\section{In Arabic:}

1. Hassan Mohamed Al-Nawasrah: Persons with Special Needs, An Introduction to Physical Rehabilitation, $1^{\text {st }}$ edition, Dar AlWafaa for Printing and Publication, Alexandria. 2002.

2. Seddiq Mohamed Tolan: Exercise Theories and Basics, Faculty of Physical Education, Alexandria University, 2002

3. Abdel Monem Soleiman Borhom and Mohamed Khamis Abu Nemra: Encyclopedia of Sport Exercises, Part I, $2^{\text {nd }}$ edition, Dar Al-Fikr for Publication and Distribution, 1995.

4. Ateyat Mohamed Khattab: Exercises for Girls, $8^{\text {th }}$ edition, Dar Al-Maaref, 1997.

5. Fathy Ahmed Ibrahim: The Effect of Developing Warm-Ups and Exercises in the Physical Education Lesson on the Skillful Performance of Elementary Education Gymnastics, unpublished dissertation for the Ph. D. Degree, Faculty of Physical Education, Alexandria University, 1982.

6. Moussa Fahmy Ibrahim and Adel Mohamed Hassan: Exercises and Sport Shows, $9^{\text {th }}$ edition, Dar Al-Maaref, 1999.

7. Aulivola B, Hile CN, Hamdan AD, et al. Major lower extremity amputation: outcome of a modern series. Arch Surg. 2004;139(4):395-9; discussion 399.

8. Casale R, Alaa L, Mallick M, Ring $\mathbf{H}$. Phantom limb related phenomena and their rehabilitation after lower limb amputation. Eur J Phys Rehabil Med. 2009;45(4):559-566

9. Cole ESPT. Training elders with transfemoral amputations. Topics in Geriatric Rehabilitation.Functional Mobility. 2003;19(3):183-190.

10. http://ovidsp.ovid.com/ovidweb.cgi?T=JS $\& N E W S=N \& P A G E=$ fulltext $\& A N=000136$ 14-200307000-00004\&D=yrovftf.

11. Darnall BD. Self-delivered home-based mirror therapy for lower limb phantom 
pain. Am J Phys Med Rehabil. 2009;88(1):78-81.

12. Dillingham TR, Pezzin LE, MacKenzie EJ. Limb amputation and limb deficiency: epidemiology and recent trends in the United States. South Med J. 2002;95(8):875-883.

13. Dillingham TR, Pezzin LE, Mackenzie EJ. Discharge destination after dysvascular lower-limb amputations. Arch Phys Med Rehabil. 2003;84(11): 662-668.

14. Esquenazi A. Amputation rehabilitation and prosthetic restoration. From surgery to community reintegration. Disabil Rehabil. 2004;26(14-15):831-836.

15. Knetsche RP, Leopold SS, Brage ME. Inpatient management of lower extremity amputations. Foot Ankle Clin. 2001;6(2):229-241.

16. Kohler F, Cieza A, Stucki G, et al. Developing Core Sets for persons following amputation based on the International Classification of Functioning, Disability and Health as a way to specify functioning. Prosthet Orthot Int. 2009;33(2):117-129.

17. MacLachlan M, McDonald D, Waloch J. Mirror treatment of lower limb phantom pain: a case study. Disabil Rehabil. 2004;26(14-15):901-904.

18. Marzen-Groller KD, Tremblay SM, Kaszuba J, et al. Testing the effectiveness of the Amputee Mobility Protocol: a pilot study. J Vasc Nurs. 2008;26(3):74-81.

19. Murray CD, Pettifer S, Howard T, et al. The treatment of phantom limb pain using immersive virtual reality: three case studies. Disabil Rehabil. 2007;29(18):14651469.

20. Seymour R. Prosthetics and Orthotics: Lower Limb and Spinal. Lippincott Williams \& Wilkins; 2002:485.

21. Taylor SM, Kalbaugh CA, Blackhurst DW, et al. Preoperative clinical factors predict postoperative functional outcomes after major lower limb amputation: an analysis of 553 consecutive patients. J Vasc Surg. 2005;42(2):227-235.

22. van Velzen AD, Nederhand MJ, Emmelot CH, Ijzerman MJ. Early treatment of transtibial amputees: retrospective analysis of early fitting and elastic bandaging. Prosthet Orthot Int. 2005;29(1):3-12.
23. Panesar BS, Morrison P, Hunter J. A comparison of three measures of progress in early lower limb amputee rehabilitation. Clin Rehabil. 2001;15(2):157-171.

24. Pauley T, Devlin M, Heslin K. Falls sustained during inpatient rehabilitation after lower limb amputation: prevalence and predictors. Am J Phys Med Rehabil. 2006;85(6):521-32; quiz, 533-5.

25. Pasquina PF, Bryant PR, Huang ME, Roberts TL, Nelson VS, Flood KM. Advances in amputee care. Arch Phys Med Rehabil. 2006;87(3 Suppl 1):S34-43; quiz S44-5.

26. Zidarov D, Swaine B, Gauthier-Gagnon C. Quality of life of persons with lower-limb amputation during rehabilitation and at 3month follow-up. Arch Phys Med Rehabil. 2009;90(4):634-645. 
